\title{
Researching Slovenian Media in Transition: Situating Knowledge
}

\author{
Jurij Smrke
}

\section{| Why?}

The most appropriate question to ask at the beginning of any kind of text is, I believe, "why?" Why am I writing this? Why is the chosen topic important? Why to me, why to the reader, why to an inhabitant of Slovenia, and why to anyone else? These questions require answers before any other steps are taken. They are the base that determines the outcome.

Twenty years after the inhabitants of Slovenia decided in one voice (95\%) to split from SFR Yugoslavia, in the midst of a worldwide crisis of capitalism, and very much in sync with the premiere of a South Park episode featuring Capitan Hindsight, there was one question that seemed very important to a great number of people. Starting of as a slogan for a round table organized by Slovenia's third largest daily (Dnevnik) the words "Is this what we fought for?" became one of the focal points of the media debate surrounding this national anniversary. Is what we have after twenty years of transition to capitalism, what we have opted for in 1990? Responses that came from various politicians, analytics and opinion leaders went in the general direction that is implied in the question: The country has problems and this is not what people expected. "People expected a normal system, but now they are disillusioned, because they expected more (Bajec 2010)." Of course many public speakers used the opportunity to praise the time of gaining independence as magical, as a symbol of what Slovenians can really achieve if only they unite, thereby renewing the layer of mythological polish surrounding that time. All in all only one answer to the question, caught my attention and it came from the mouth of Milan Kučan, former president of Slovenia and also an important figure in ex-Yugoslavia. "Yes, this is exactly what we fought for," he stated (Kolednik 2010). Now, Kučan did not mean to say that people should stop fooling themselves and accept that unemployment, pauperization and elitization of education are what capitalism is (also) about, he was talking about how being independent was what "we" fought for and that that is what has been achieved and matters the most (thereby strengthening the myth). He did not mean to say that as a socialist state with an extensive tradition in Marxist studies "we" were very well aware of the flaws of the market, profit maximization, deregulation and still decided to choose them as governing principles, but in a way he still said it. There lies a greater truth behind his quote, which is as Gal Kirn (Kirn 2011: 36) put it in his analysis of liberalism in SFRY: "We doubt that it is too much to say that the referendum of 1990 would have had a different outcome, had the question been: Fellow Slovenians, do you agree to witness, in the next decade, an augmentation of class differences and unemployment, a reduction of holidays and pensions and the privatization of health care ...?"

Before I can answer the opening questions, something else needs to be stated. Tonči Kuzmanić (2003: 9) explains that the crucial element of the post-socialist transition attitude is the mythological "satanization of socialism", construction of socialism as "unnatural", that it is actually the same as "communism", which is furthermore the same as "stalinism", which is the same as "totalitarianism" and is as such in the utmost contradiction with human nature as well as the nature of history and morality. So we have, on the one hand, the first doubts about the new order, and on the other a climate that makes it difficult to think of it in Marxist terms: "What are you talking about? Socialism didn't work anyway."

This is why questions surrounding transition are important. They are the historical battlefield that can either 
reinforce dominant views or give birth to new ones. I would like to think of communism anew. This is a very honest and simplistic answer, but it still matters. It is an expression of the historical circumstances in which my generation is intellectually maturing. These circumstances (I speak here of the dominant discourses in Slovenian media and public sphere) do not offer an interpretation of history that would allow new ways of thinking about the past and therefore the present. It is because of this, that it needs to be created.

\section{How \#1}

This should give away that I do not consider the "objective scientific method" to be the key to analysis. Rather I believe that it is inadequate because of three myths that surround it: the myth of one, indivisible and uniform truth, the myth of a reality separated from discourse and of course the myth of the magical procedures that allow us to extract an innocent truth from an innocent reality (Krašovec 2003: 35). To resolve the danger of relativism that threatens this position, I will adopt the model of situated knowledges, developed by Donna Haraway (1999). This means that I will speak and observe from a particular position. This position is firstly a position of a youth, that was born in SFRY, but grew up in Slovenia, and secondly a position of an editor of a marginalized magazine with Marxist tendencies. This does not mean that I will be more right than others, because I am in a somewhat peripheral position. Situated knowledges are not located in concrete bodies of individuals, but rather work "through responsible floating in the field of differences." (Krašovec 2003: 35) Differences is the crucial word here. The power of the current dominant discourses - positivism in natural science, behaviorism in sociology and psychology, neoliberalism in politics and economy, objectivity in journalism - is that it formally neutralizes differences. No matter who you are, as long as you follow such and such procedures, the truth is available to you (the autonomy is "taken" from the players and "given" to the discourse itself). However, because these procedures are always the same, reality is always structured in the same way and so "despite of all the "discoveries" and "advances" the structure of the dominant discourses remains the same, which means that also the effects of power of these discourses remain the same." (Krašovec 2003: 37) In neutral speech differences seem irrelevant and the neutral speech itself is not capable of seeing the real effects of these differences, that can only work in a discriminatory fashion when in the system of equality. This (also) means that when assuming a subjective position you will be disqualified by a speaker, who defends the "objective" position, as being ideologically biased and/or interest guided. Of course, you have all the options not to spread your subjective drivel, leave your ideology at home and just come to discuss facts. So you are equal, but not equal and that is your own fault.

It suffices to say that such a view is of course also ideological. In order to avoid relativism, to be able to assume a position in this debate, I need to state, as Haraway did, that my marginal position deserves preferential treatment (1999: 305): "The standpoint of those subject are not innocent positions. On the contrary, they get preference because it is in principle the least possible that they will allow the denial of the critical and interpretative core of all knowledge (translation from Slovenian by J. S.)."

Now that this has been said I need to focus on another problem. Since I am trying to build a basis for exploring the history of the media in order to produce new knowledge, I seem to have a problem. Situated knowledges are concrete life experiences of marginalized persons, be it those colonized, those without property, or those racially, sexually or ethnically labeled. The situated knowledge I intend to produce is not knowledge about something I have lived, but about something that I access in the same manner anyone else does - through (historical) sources. In this perspective I only have the concrete life experience that triggered the need for knowledge that would be fruitful for the situation I'm in, but not the material that goes with it. The question is, does this make a difference? It seems that having lived through something gives one the privilege to take up a position and speak from it with preference in relation to those who have not done so. I believe that having had the direct contact does not matter as much as "not allowing the denial of the critical and interpretative core of all knowledge." In the end the information a feminist (as in Haraway's case) draws upon is not only what he or she has experienced in his or her lifetime, but also what one might learn from history or other conceptualizations of his or her particular situation. The point of interest in this case is not so much that knowledge is situated with us (that is the knowledge that is culturally available to us), but how we situate knowledge, what view and interpretation we have chosen or believe to not have chosen.

To sum up. I have chosen to build a basis for exploring Slovenian media in transition from a perspective of a youth that is disillusioned about the way in which the majority of the post-socialist media work. Since their 
functioning is deeply connected with the socio-economical circumstances that be, this perspective is one based on the critique of capitalism. Since in recent history of the geopolitical region concerned, much has been tried and much has failed on the same basis, the aim of this text is to set up some ideas that could enable us to think about communism and the media again. Ideas that would enable us to act politically again.

\section{How \#2}

This leaves us with another question of method. On what basis can we think about communism and the media all over again? One way would be to use the same general tactic I used in coming to grips with objectivity. That would mean taking the dominant diagnoses of the media in Socialist Federative Republic of Yugoslavia and comparing them to what we have today. A very popular statement about the time between 1945 and 1990 is that it lacked freedom. A response to that would be to take todays media and show that they're not exactly free either or that oppression is at work in a different way. But this has mostly been achieved (Močnik 1985, Bašić-Hrvatin 2004, 2005, 2007), at least in the academic circle, so we can only add something to it or spread the word. When we are asking what to cling on when rethinking the whole situation, this approach tells us what we already know - that we should rethink.

In order to illustrate what kind historical research/attitude is needed I will digress on a topic that speaks very clearly of the "nature" of historical memory and transition. It is the topic of reconciliation. "National reconciliation was one of the key program points that hegemonized Slovenian political space from the mid " $80 \mathrm{~s}$ on. The first flags were of course raised by adherents of the right, with the catholic church at the front. The fight for a new interpretation of history was crucial in forming Slovenliness and disguising social conflicts in a nationalistic robe." (Kirn 2011b: 12) The discourse of reconciliation was especially strong in times of crisis, when the divisions between Slovenians were often put forward as an obstacle for reforms. Crucial are the events of World War II. Reconciliation became a synonym for the condemnation of after-war killings of the collaborators with the occupational Nazi regime, carried out by the revolutionary forces under Tito. "The ideology of reconciliation succeeds in leveling domobranstvo (collaborators - note that domobranec in direct translation means home defender; $\mathrm{A} / \mathrm{N}$ ) with partisans and at the same time condemning the "totalitarian" regime that appeared out of the war. Out of this seeming equalization domobranci come as moral victors that had nothing to do with the criminal regime. Of course the collaboration is kept silent. Reconciliation will accordingly set in as soon as we will be ashamed of communism and will approve fascism (Kirn 2011b: 12).”

The left, considered as the heir of the former regime, was and is expected to condemn the killings. They have done so and started to defend only the national aspect (how the liberation fight freed Slovenia from the Germans, Italians and Hungarians) of the partisans' fight. This element of reconciliation has successfully covered up the revolutionary nature of the resistance. The left has accepted the moralizing discourse that was set up by the right. The prevailing debate about WWII was concerned with counting bodies. However, what the resistance also achieved is doing away with the old pre-socialist Yugoslavia, "which was based on the hegemony of the Serbian national leadership, political repression and the exploitation of laborers and farmers (Kirn 2011b: 12)". In this way the fight was doubtlessly a progressive one.

\section{Synthesis}

We see that rethinking reconciliation gives us a new perspective, that was mostly absent from general discourse. There were nationalisms and a general condemnation of the apparently dark and monolithic socialist era which were at best mixed with nostalgia, but there were no cracks presented and no positions assumed, except those based on Christian morality, collaboration and after-war killings. This is a very superficial "victory", basically fueling the patriotic drive that is supposed to lead Slovenia to another decade of "freedom and prosperity". And this is the exact same equality rhetoric that I mentioned before. Through annihilating differences it works discriminatory.

At this point differences are crucial. One needs to assume a position and one needs to open up cracks. "To show a historical event through the dispersed multitude of evitability - to show something, that was not carried out, but was present as potential. That opens a crack in the present, which allows a different understanding of the order of 
things (Bobnič 2011: 16)".

Rethinking reconciliation made visible the possibility of a monarchic rule after the war. In a similar manner Gal Kirn (2011a) has shown that liberalism in SFRY is a product of the 1960s. Had the fights between different currents inside the League of Communists gone another way, maybe there would be more left of socialism. This perspective fights the prevailing view that the end of socialism was a historical necessity and a result of the 1980s. Very broadly speaking we may now see the regression to capitalism as a result of (previously existing) liberalist tendencies mixing with growing nationalisms. We cannot understand it if we think of it "as a consequence of some irrational character of the Balkan nations or superficially as a consequence of totalitarian repression of Titoistic rule. Crucial for the disintegration of Yugoslavia were political and intellectual efforts of the liberals (Kirn 2011: 26) ...”

\section{Synthesis and the Media}

On the base of all this I will now draw some conclusions/guidelines in connection to media research from the position of a Marxist thinker in post-socialist Slovenia (and maybe wider):

- One should try to compare the two media systems on the basis of the ideals we hold important (for example freedom, autonomy, objectivity, advocacy ...).

- One should question the conceptions of these ideals by applying genealogical analysis to them and "opening up cracks".

- One should assume an openly ideological/political/conceptual position in facing the past media system and demask other positions as ideological.

- One should recognize the achievements that were progressive in regard to the past, the present and one's own political position, even if they show to have or seem to have contained flaws.

- One should discuss the achievements that seem applicable for the understanding or improving of his or her position.

- One should diagnose the flaws and try to correct them never allowing the denial of the critical and interpretative core of all knowledge.

\section{References}

Bajec, Niko. 2010. A smo se za to borili? Ljudje so pričakovali nek normalen sistem a so razočarani Dnevnik. Available from: http://www.dnevnik.si/novice/slovenija/1042409941 (May $30)$.

Bašić Hrvatin, Sandra and Lenart J. Kučič. 2005. Monopoli: Družabna igra trgovanja z mediji. Ljubljana: Maska.

Bašić Hrvatin, Sandra et al. 2004. Medijsko lastništvo. Ljubljana: Mirovni inštitut.

Bašić Hrvatin, Sandra and Brankica Petković. 2007. In temu pravite medijski trg? Ljubljana: Mirovni inštitut.

Bobnič, Robert. 2011. Proti-spominu. Tribuna, January. Retrieved from: http://www.tribuna.si/casopis/Tribuna_januar_2011.pdf (May 20).

Haraway, Donna. 1999. Opice, kiborgi in ženske: reinvencija narave. Ljubljana: Študentska založba.
Kirn, Gal. 2011a. Nacrt tranzicije u kapitalističkoj nacionalnoj državi kao projekat liberalnog proleća, odnosno killing us softly na slovenački način. IN Kroz tranziciju: prilozi teoriji privatizacije. ed. Željko Popović and Goran Gajić, 21 - 43. Novi Sad: Ako.

---- 2011b. Sprava; nacionalistična ideologija slovenstva; zagovor domobranstva $\mathrm{z}$ desne fronte. Tribuna, January. Retrieved from: http://www.tribuna.si/casopis/Tribuna_januar_2011. pdf (May 20).

Kolednik, Aleksander. 2010. Smo se borili za to, kar imamo danes: Da, natančno za to. RTVSLO MMC. Available from: http://www.rtvslo.si/slovenija/kucan-smo-se-borili-za-to-karimamo-danes-da-natancno-za-to/246990 (May 30).

Krašovec, Primož. 2003. On objectivity. Ljubljana: FDV.

Kuzmanić, Tonči A. 2003. Postsocializem kot vzhodna oblika reaganizma in thatcherizma. IN

Neokonzervativizem, ed. Ciril Oberstar in Tonči A. Kuzmanić, 7-14. Ljubljana: Mirovni

inštitut. 
Močnik, Rastko. 1985. V boju za svobodo javne besede - danes. IN Cenzura in svoboda tiska, ed. Mojca Dobnikar and Vlasta Jalušič. Ljubljana : Republiška konferenca ZSMS : Univerzitetna konferenca ZSMS. 
